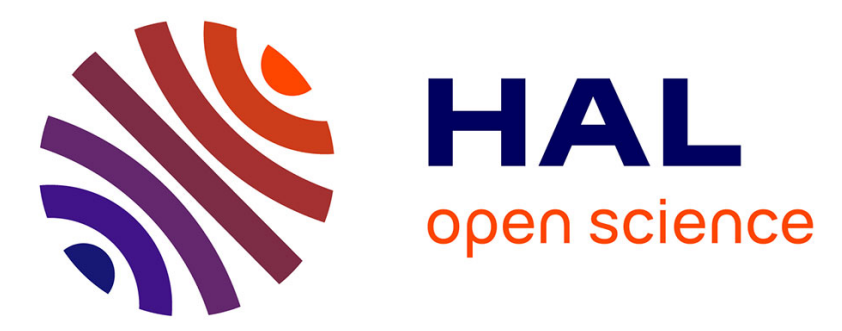

\title{
A better alternative to dynamic programming for offline energy optimization in hybrid-electric vehicles
}

Mouloud Guemri, Sandra Ulrich Ngueveu, Stéphane Caux, Frédéric Messine

\section{To cite this version:}

Mouloud Guemri, Sandra Ulrich Ngueveu, Stéphane Caux, Frédéric Messine. A better alternative to dynamic programming for offline energy optimization in hybrid-electric vehicles. 11th International Workshop of Electronics, Control, Measurement, Signals and their application to Mechatronics (ECMSM 2013), Jun 2013, Toulouse, France. pp.1-2, 10.1109/ECMSM.2013.6648937 hal-01178570

\author{
HAL Id: hal-01178570 \\ https://hal.science/hal-01178570
}

Submitted on $20 \mathrm{Jul} 2015$

HAL is a multi-disciplinary open access archive for the deposit and dissemination of scientific research documents, whether they are published or not. The documents may come from teaching and research institutions in France or abroad, or from public or private research centers.
L'archive ouverte pluridisciplinaire HAL, est destinée au dépôt et à la diffusion de documents scientifiques de niveau recherche, publiés ou non, émanant des établissements d'enseignement et de recherche français ou étrangers, des laboratoires publics ou privés. 


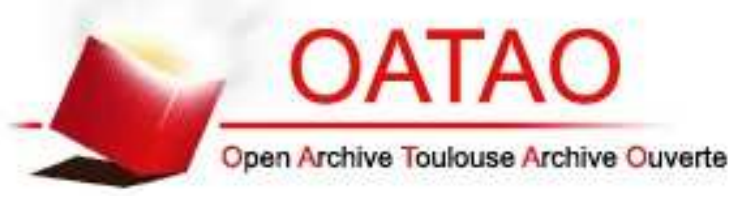

\section{Open Archive TOULOUSE Archive Ouverte (OATAO)}

OATAO is an open access repository that collects the work of Toulouse researchers and makes it freely available over the web where possible.

This is an author-deposited version published in : http://oatao.univ-toulouse.fr/ Eprints ID : 13010

URL: http://dx.doi.org/10.1109/ECMSM.2013.6648937

To cite this version : Guemri, Mouloud and Ngueveu, Sandra Ulrich and Caux, Stéphane and Messine, Frédéric $A$ better alternative to dynamic programming for offline energy optimization in hybrid-electric vehicles. (2013) In: 11th International Workshop of Electronics, Control, Measurement, Signals and their application to Mechatronics (ECMSM), 24 June 2013 - 26 June 2013 (Toulouse, France).

Any correspondance concerning this service should be sent to the repository administrator: staff-oatao@listes-diff.inp-toulouse.fr 


\section{A better alternative to dynamic programming for offline energy optimization in hybrid-electric vehicles}

\author{
Mouloud Guemri \\ LAPLACE, UMR CNRS 5213, INPT, UPS, \\ 2 rue Camichel, 31071 Toulouse, France \\ Univ de Toulouse, INP, F-31400 Toulouse, France \\ Email: \{guemri\}@laplace.univ-tlse.fr
}

Sandra Ulrich Ngueveu

CNRS ; LAAS ; 7 avenue du colonel Roche, F-31077 Toulouse Cedex 4, France

Univ de Toulouse, INP, LAAS, F-31400 Toulouse, France

Email: ngueveu@laas.fr

\begin{abstract}
This article focusses on the well-known problem of energy management for hybrid-electric vehicles. Although researches on this problem have recently intensified. Dynamic programming (DP) is still considered as the reference method because it obtains the best solutions of the literature so far, even though it requires a significant computational time. This article however, describes two heuristic-global-optimization-based algorithms that not only require less computational time than DP, but also produce better solutions, with significantly lower fuel consumption cost.
\end{abstract}

Keywords - Hybrid-Electric Vehicles; Heuristics; Lower Bound; Global Optimization

\section{INTRODUCTION}

Before the last decade there was no crisis in fossil fuels and the Hybrid-electric vehicle (HEV) diffusion was hindered by the technology of electrical energy storage. Now, the ecodesign, sustainable development and the price of a barrel of oil, rendered HEV promotion necessary. Their name refers to the use of at least two different energy sources for propulsion of the vehicles, for example: (1) a fuel cell with an hydrogen tank, non-reversible and that can only furnish a limited power quantity at a time, combined with (2) a battery or super capacitor which can store energy recovery and give it back later. Combining such architecture with smart power management reduces considerably the fuel consumption [1]. The challenge is to minimize the overall cost of fuel consumption for a given vehicle that follows a given profile of power demand, by optimizing the distribution of power on the two sources, in the presence of several constraints of availability, performance and state of charge of the super-capacitor. Among the prolific research on the topic, dynamic programming (DP) remains the reference method that obtains solutions with the best fuel consumption [2].

This paper describes a filtering-based and a heuristic optimization-based algorithm that can obtain solutions of a significantly lower fuel consumption cost than the solutions obtained from DP.

\author{
Stéphane Caux \\ LAPLACE, UMR CNRS 5213, INPT, UPS, \\ 2 rue Camichel, 31071 Toulouse, France \\ Univ de Toulouse, INP, F-31400 Toulouse, France \\ Email: $\{$ caux $\} @$ laplace.univ-tlse.fr \\ Frédéric Messine \\ ENSEEIHT-IRIT, UMR-CNRS 5055, \\ 2 rue Camichel, 31000 Toulouse, France \\ Email: frederic.messine@enseeiht.fr

\section{MATHEMATICAL FORMULATION} \\ The problem consists in finding at each instant the optimal \\ power split between two energy sources (e.g. a fuel-cell and \\ storage element such as a super capacitor) to satisfy the power \\ demand of a driver on a predefined road section. The objective \\ is to minimize the total fuel consumption of the vehicle, taking \\ into account the non-linear of yield functions and limitations
} of each energy source.

As proposed in [3] it can be formulated as the following optimal control problem:

$$
\begin{aligned}
& \min _{u}-\int_{0}^{T} f_{c}(u(s)) d s \\
& \dot{x}=-f_{B}(x, r-u) \\
& \text { subject to (s.t.) } \quad=x_{0}, x(T)=x_{f} \\
& 0 \leq u \leq u_{\max } \\
& x(0)=r-K_{\min } \\
& r-K_{\max } \leq u \leq r \leq x_{\max }
\end{aligned}
$$

where $r$ is fixed and represents the power requested by the powertrain, $u$ (resp. $r-u$ ) represents the power produced by the fuel cell (resp. storage element), $x$ represents the state of charge of the storage element and $f_{c}$ (resp. $f_{B}$ ) are known functions, that take into account the energy loss that happen during any energy transfer. This optimal control problem has constraints on the control action and bounds on the state of variable, rendering difficult the application of the Pontryagin principle, because of the complexity the resulting Hamiltonian equations.

Note that this problem is naturally time-discretized because $r$ 's, $f_{c}$ 's and $f_{B}$ 's data are obtained experimentally. It is therefore possible, instead of interpolating the data points for a continuous formulation of the problem, to directly solve its time-discretized version where $r_{i}$ is the power required at instant $i$, with $i$ an integer varying from 1 to $n, n$ being the number of data points obtained experimentally, and this without any loss of precision. 


\section{LITERATURE REVIEW}

Although researches on this problem has recently intensified. Dynamic programming is still considered as the reference method, because it provided the best known solutions, although it can require a significant amount of computational time [2].

Several other approaches have been proposed in the literature, such as Equivalent Consumption Minimization Strategy (ECMS), Genetic algorithms, Fuzzy logic, Rule-based, Thermostat ... [4],[5],[6]. All these methods can be much faster than DP, but to the best of our knowledge, none of them found solutions of better quality than DP. Therefore, there is a widespread perception that DP provides the optimal solution of such problems as it is stated in [7].

A recent paper of Pérez and Garcia [3] proposed a direct transcription approach using the non-linear solver MINOS that uses a projected augmented Lagrangian algorithm. Unfortunately, no comparison to the literature or previous publications was provided. However, The authors mentioned the high sensitivity of the resulting code to parameters settings.

\section{The Proposed RESOLUTION METHODS}

\section{A. Power filtering on the fuel cell: Algo. A}

This heuristic is inspired from electrical filters and aims at limiting the range of usage of the fuel cell to the best portions of its efficiency function. It requires two parameters: (1) $B_{l}$ called the lower band is chosen between 0 and the maximum power the fuel cell can provide, whereas (2) $B_{u}$ called the upper band must be strictly higher than $B_{l}$ and less than the maximum power the fuel cell can provide. Let $v_{i}$ be the power generated or stored by the storage element at time $i$. The heuristic works as follows:

- $\quad$ if $r_{i} \leq B_{l}$, then set $v_{i}=r_{i}$ and $u_{i}=0$

- $\quad$ if $B_{l} \leq r_{i} \leq B_{u}$, then set $u_{i}=r_{i}$ and $v_{i}=0$

- $\quad$ if $r_{i} \geq B_{u}$, then set $u_{i}=B_{u}$ and $v_{i}=r_{i}-B_{u}$

The short computational time required by this heuristic allows the user to fine-tune $B_{l}$ and $B_{u}$ after just a few attempts. The difference between this heuristic and the well-known "Thermostat" [5] is that the latter filtered the power required by looking at the storage element and not at the fuel cell efficiency function as it is done for our heuristic.

B. Subgradient optimization-based local search from a deterministic starting point: Algo. B

Taking advantage of the time-discretization, we reformulated the problem as a non-linear problem with non-linear constraints using decision variables: (i) $u_{i} \geq 0$ equal to the power generated by the fuel cell at time $i$, (ii) $v_{i}$ equal to the power generated (if $v_{i} \geq 0$ ) or stored (if $v_{i} \leq 0$ ) by the storage element at time $i$.

$$
\begin{gathered}
\min \sum_{i=1}^{n} f_{c}\left(u_{i}\right) \\
u_{i}+v_{i} \geq r(i), \quad \forall i \in[1, \ldots, n] \\
\sum_{i=1}^{n}\left(v_{i}+\tilde{\rho}\left(v_{i}\right)\right)=0
\end{gathered}
$$

$$
\begin{array}{ll}
\sum_{k=1}^{i}\left(v_{k}+\tilde{\rho}\left(v_{k}\right)\right) \leq x_{0}-x_{\text {min }}, & \forall i \in[1, \ldots, n] \\
\sum_{k=1}^{i}\left(v_{k}+\tilde{\rho}\left(v_{k}\right)\right) \geq x_{0}-x_{\text {max }}, \quad \forall i \in[1, \ldots, n]
\end{array}
$$

where $\tilde{\rho}\left(v_{i}\right)$ is the amount power lost when SE generates or receives $v_{i}$.

This heuristic consists in applying subgradient optimization on this formulation. Although the idea is similar to [3]. The main challenge of such approach remains that it can be assimilated to a local search, and as such its efficiency is strongly dependent on the starting point chosen. Using random initial solutions leads to poor results and an increased computational time. Finding the best starting point is key, and our algorithm uses a predefined starting point corresponding exactly to the power required $r$.

\section{RESUlts OBTAined}

Table I summarizes the results obtained in comparison to the DP from [2], using the same powertrain characteristics and the power profiles provided by INRETS and ALSTOM (ESKISEHIR) with a time sampling of $1 \mathrm{~s}$. All implementations were done with MATLAB R2009 on a $2.80 \mathrm{Ghz}, 3 \mathrm{~Gb}$ RAM PC. Results show an improvement of more than $13 \%$ on the

TABLE I. RESULT OF OUR HEURISTICS VS DP

\begin{tabular}{|c|c|c|c|c|}
\hline & & DP & Algo. A & Algo. B \\
\hline INRETS & Fuel cost & 10131 & 8869 & 8750 \\
\hline & Computing time & $22 \mathrm{~h}$ & $5 \mathrm{~s}$ & $23 \mathrm{~min}$ \\
\hline ESKISEHIR & Fuel cost & 31826 & 28365 & 27601 \\
\hline & Computing time & $52 \mathrm{~h}$ & $5 \mathrm{~s}$ & $10 \mathrm{~h}$ \\
\hline
\end{tabular}

fuel consumption cost from the solution from DP.

\section{CONCLUSION}

For offline energy optimization in hybrid-electric vehicles, our algorithms based on global optimization produce solutions of significantly lower fuel consumption cost than the solutions from the dynamic programming. They should therefore be used from now on instead of DP to generate reference solutions.

\section{REFERENCES}

[1] L. Wang and H. Li, Maximum fuel economy-oriented power management design for a fuel cell vehicle using battery and ultracapacitor. IEEE Trans.Ind. Appl., 46(3), pp. 1011-1020, May/Jun. 2010.

[2] S. Caux and W. Hankache and M. Fadela and D. Hisselb On-line fuzzy energy management for hybrid fuel cell systems. Int. J. of Hydrogen Energy, 35(5), pp. 21342143, 2010.

[3] L.V. Pérez and G. O. Garcia, State Constrained Optimal Control Applied to Supervisory Control in HEVs. Oil \& Gas Science and Technology Rev. IFP, 65 (1), pp.191-201, 2010.

[4] T. Hofman and M. Steinbuch and R. van Druten and A. Serrasens Rulebased energy management strategies for hybrid vehicles. Int. J. Electric and Hybrid Vehicles, 1(1), pp. 71-94, 2007.

[5] N. Jalil and N. A. Kheir and M. Salman, A rule-based energy management strategy for a hybrid series vehicle. Proceedings of the American Control Conference, pp.689-693, 1997.

[6] C. Shen and P. Shan and T. Gao, A comprehensive overview of hybrid electric vehicles. Int. J. of Veh. Tech., Article ID 571683, 7 p., 2011.

[7] P. Pisu and G. Rizzoni, A comparative study of supervisory control strategies for hybrid electric vehicles. IEEE Trans. Cont. Syst. Tech., 15(3), pp. 506-518, 2007. 